\title{
Strontium Doped Hydroxyapatite Nanoparticles: Synthesis, Characterization and Simulation
}

\author{
ZHOU Zihang ${ }^{1}$, WANG Qun ${ }^{2}$, GE Xiang ${ }^{3}$, LI Zhaoyang ${ }^{1}$ \\ (1. School of Materials Science and Engineering, Tianjin University, Tianjin 300350, China; 2. College of Life Science and \\ Biotechnology, MianYang Teachers' College, Mianyang 621006, China; 3. Key Laboratory of Mechanism Theory and Equip- \\ ment Design of Ministry of Education, School of Mechanical Engineering, Tianjin University, Tianjin 300354, China)
}

\begin{abstract}
Strontium (Sr) doped hydroxyapatite (HA) has been widely used in diverse biological applications. In this work, hydrothermal synthesis method was used to prepare HA and Sr doped HA nanoparticles. A series of experimental methods and the simulation method based on density functional theory (DFT) were used to investigate the effect of $\mathrm{Sr}$ doping on chemical composition, crystallinity, lattice parameters, morphology, and formation energies of HA. The experimental results indicated that the lattice parameters and crystal size of Sr doped HA nanoparticles increased. The crystallinity of $\mathrm{Sr}$ doped HA nanoparticles did not change significantly with the increasing concentration of $\mathrm{Sr}$ ions. The lattice parameters obtained by the simulation method were in good agreement with the experimental results. The formation energies indicated that $\mathrm{Sr}$ ion doping endowed the structure more stable, which also illustrated that the $\mathrm{Ca}(1)$ site was the preferential site for $\mathrm{Sr}$ doping at 10at\% and mixed doping was a more preferred doping mode at $50 \mathrm{at} \%$.
\end{abstract}

Key words: hydroxyapatite; strontium doping; lattice parameter; density functional theory; formation energy

Hydroxyapatite (HA) has been widely used as a bioceramic with good biological activity. HA plays an important role in dental and bone regeneration due to its superior biocompatibility and excellent ability to bond bone tissue ${ }^{[1]}$. However, the crystallinity, morphology, and other physical properties are different between biological apatites and pure $\mathrm{HA}^{[2]}$. In order to modify the solubility and degradation of HA, as well as to add some additional biological and antibacterial properties, many techniques have been employed ${ }^{[3-4]}$. Recently, introducing extrinsic ions, such as $\mathrm{Zn}^{2+[5]}, \mathrm{Ba}^{2+[6]}, \mathrm{F}^{-[7-10]}$, into an apatite structure is the most practicable and effective method to solve these problems.

$\mathrm{Sr}$ is proved to be one of the most constituent elements in bones. It has been extensively utilized to endow HA with better performances, such as higher biocompatibility and bioactivity, due to its excellent biocompatibility ${ }^{[11-12]}$. In vivo and in vitro studies have demonstrated that Sr doping can significantly accelerate differentiation of osteoblast cells and inhibit proliferation of osteoclast cells $^{[13-14]}$. The stoichiometric component of $\mathrm{HA}$ is $\mathrm{Ca}_{10}\left(\mathrm{PO}_{4}\right)_{6}(\mathrm{OH})_{2}$ and the unit cell of it belongs to $\mathrm{P}_{3} / \mathrm{m}$ space group which has a $\mathrm{C} 3$ symmetry ${ }^{[15]}$. The Sr ions HA hexagonal structure can be doped into two types of $\mathrm{Ca}$ sites $[\mathrm{Ca}(1) \text { and } \mathrm{Ca}(2)]^{[16]}$. Four of the ten $\mathrm{Ca}$ sites, named as $\mathrm{Ca}(1)$, form channels parallel to the $c$-axis. Remaining six of the ten $\mathrm{Ca}$ sites, denoted as $\mathrm{Ca}(2)$, are located as two symmetrical triangles around hydroxyl channels ${ }^{[17-18]}$. Previous studies found that $\mathrm{Sr}$ ions could enter these two types of $\mathrm{Ca}$ sites without solubility limita$\operatorname{tion}^{[19]}$. It is worth noting that $\mathrm{Sr}$ ions shows different site preference during the process of doping. Terra et al. ${ }^{[20]}$ studied the site preference of Sr doping by Rietveld refinement of X-ray diffraction patterns when the doping molar concentrations of $\mathrm{Sr}$ are below 1\%. Their results showed that the $\mathrm{Ca}(1)$ sites are the preferential site for $\mathrm{Sr}$ doping. Zeglinski et al.$^{[17]}$ utilized the density functional theory (DFT) method to study the most preferential mode and revealed that the mixed substitution occurred at $\mathrm{Ca}(1)$ and $\mathrm{Ca}(2)$ sites randomly and $\mathrm{Ca}(2)$ sites become the

Received date: 2019-08-22; Revised date: 2019-11-26

Foundation item: National Natural Science Foundation of China (51871163); Natural Science Foundation of Tianjin (18JCYBJC19500); Scientific Research Startup Program of Mianyang Teachers' College (QD2019A20)

Biography: ZHOU Zihang (1993-), male, Master candidate. E-mail: 1047944845@qq.com 周子航(1993-), 男, 硕士研究生. E-mail: 1047944845@qq.com

Corresponding author: LI Zhaoyang, professor. E-mail: zyli@tju.edu.cn; GE Xiang, assistant professor. E-mail: gexiang.hkust@gmail.com 李朝阳, 教授. E-mail: zyli@tju.edu.cn; 葛 翔, 助理教授. E-mail: gexiang.hkust@gmail.com 
preferential sites with the increase of substitution concentration of Sr ions. Bigi et al. ${ }^{[19]}$ reported a preference for the $\mathrm{Ca}(2)$ substitution at or above $10 \mathrm{at} \%$ of $\mathrm{Sr}$, while $\mathrm{Ca}(1)$ was preferred at $5 \mathrm{at} \%$ of $\mathrm{Sr}$. So far, there is still a controversy regarding the preferred doping sites of $\mathrm{Sr}$ ions in the HA crystal structure.

Although there have been many theoretical and experimental studies on $\mathrm{Sr}$ doping into HA structure, few studies have combined theory with experimental results. In this study, a hydrothermal method was used to synthesize the pure HA and $\mathrm{Sr}$ doped (10at\%, 50at\%, 100at\%) HA nanoparticles. Scanning electron microscopy (SEM), $\mathrm{X}$-ray diffraction (XRD), high-resolution transmission electron microscopy (HRTEM), and selected-area electron diffraction (SAED) were employed to provide the morphology, crystallinity, and microstructure of the samples. $A b$ initio method which is based on quantum mechanics provided the lattice parameters and formation energy according to $\mathrm{Sr}$ doping concentrations. The preference sites of $\mathrm{Sr}$ ions doping for $\mathrm{Ca}$ at $10 \mathrm{at} \%$ and $50 \mathrm{at} \%$ concentration were also discussed.

\section{Materials and methods}

\subsection{Preparation of $\mathrm{HA}$ and $\mathrm{Sr}-\mathrm{HA}$}

HA $\left(\mathrm{Ca}_{10}\left(\mathrm{PO}_{4}\right)_{6}(\mathrm{OH})_{2}\right)$ and Sr-doped HA $\left(\mathrm{Ca}_{10-x} \mathrm{Sr}_{x}\left(\mathrm{PO}_{4}\right)_{6}(\mathrm{OH})_{2}, \quad x=0-10\right)$ nanoparticles with $\mathrm{Sr}$ concentrations at 10at $\%$, 50at $\%, 100 \mathrm{at} \%(x=1,5,10)$ were prepared by a hydrothermal method. Calcium nitrate tetrahydrate $\left(\mathrm{Ca}\left(\mathrm{NO}_{3}\right)_{2} \cdot 4 \mathrm{H}_{2} \mathrm{O}\right)$, strontium nitrate $\left(\mathrm{Sr}\left(\mathrm{NO}_{3}\right)_{2}\right)$, and diammonium hydrogen phosphate $\left(\left(\mathrm{NH}_{4}\right)_{2} \mathrm{HPO}_{4}\right)$ were utilized as $\mathrm{Ca}, \mathrm{Sr}$, and $\mathrm{P}$ sources, respectively. Preparation procedure of $2 \mathrm{~g}$ of $50 \mathrm{at} \%$ Sr-doped HA was as follows: $1.9 \mathrm{~g}$ of $\mathrm{Ca}\left(\mathrm{NO}_{3}\right)_{2} \cdot 4 \mathrm{H}_{2} \mathrm{O}$, $1.703 \mathrm{~g}$ of $\mathrm{Sr}\left(\mathrm{NO}_{3}\right)_{2}$, and $1.275 \mathrm{~g}$ of $\left(\mathrm{NH}_{4}\right)_{2} \mathrm{HPO}_{4}$ were dissolved into $60 \mathrm{~mL}$ deionized water. Then, $25 \% \mathrm{am}-$ monia solution was used to adjust the $\mathrm{pH}$ between 10 and 10.5. After stirring the mixture for $5 \mathrm{~min}$, it was injected into a hydrothermal reactor and aged at $150{ }^{\circ} \mathrm{C}$ for $6 \mathrm{~h}$. The precipitates obtained by centrifugation were cleaned three times with distilled water and anhydrous ethanol. Finally, the products were dried at $70{ }^{\circ} \mathrm{C}$ for $12 \mathrm{~h}$.

\subsection{Characterization of the samples}

Lattice parameters ( $a$ and $c$ ) were quantified from peaks of (002) and (211) in an XRD pattern, respectively, using the standard hexagonal close packed unit cell plane spacing relationship ${ }^{[21]}$ :

$$
\frac{1}{d^{2}}=\frac{4}{3}\left(\frac{h^{2}+k^{2}+l^{2}}{a^{2}}\right)+\frac{c^{2}}{l^{2}}
$$

where $d$ is the distance between two adjacent planes in the set of Miller indices $(h k l)$.
The degree of crystallinity ${ }^{[22]}$, corresponding to the fraction of crystalline phase present in the examined volume, was evaluated as:

$$
X_{\mathrm{c}}=1-\left(\frac{V_{112 / 300}}{I_{300}}\right)
$$

where $I_{300}$ is the intensity of (300) reflection and $V_{112 / 300}$ is the intensity of the hollow between (112) and (300) reflections, which completely disappears in non-crystalline samples.

Composition of individual apatite crystals was examined by X-ray energy dispersive spectrometer (EDS) equipped on SEM. The atomic concentrations of elements $(\mathrm{Ca}, \mathrm{P}$, and $\mathrm{Sr}$ ) in the nanoparticles were further determined by an inductive coupled plasma emission spectrometer (ICP; VISTA-MAX) method.

Surface morphology of the synthesized HA nanoparticles were observed by SEM (HITACHI S-4800, Tokyo, Japan) at an accelerating voltage of $5 \mathrm{kV}$. The phase analysis was carried out using X-ray powder diffraction instrument (RIGAKU/DMAX). The patterns were recorded using $\mathrm{CuK} \alpha$ radiation in the $2 \theta$ range of $10-90^{\circ}$ at the step size of $0.02^{\circ}$ with the scan speed of $8\left(^{\circ}\right) / \mathrm{min}$.

The microstructures of nanoparticles were examined by TEM for comparing with XRD results. TEM images were taken using a JEM-2100F microscope at $200 \mathrm{kV}$. HRTEM images and SAED patterns were also obtained.

\subsection{Computational method}

The calculations were carried out using the CASTEP module in the Materials Studio software package. The CASTEP code is an ab initio program which can calculate ground state energies of atomic systems accurately based on DFT. The two types of Ca sites $[\mathrm{Ca}(1)$ or $\mathrm{Ca}(2)]$, with four $\mathrm{Ca}(1)$ sites surrounded by nine oxygen atoms and six $\mathrm{Ca}(2)$ sites positioning around the $\mathrm{OH}$ groups, can be substituted by other doping cations. Based on the unit cell of HA, eight possible Sr-doped HA models were built.

1Sr-Ca(1)-HA model: One $\mathrm{Ca}(1)$ was replaced by one $\mathrm{Sr}$ atom in pure HA.

4Sr-Ca(1)-1Sr-Ca(2)-HA model: Four $\mathrm{Ca}(1)$ were replaced by four $\mathrm{Sr}$ atoms and one $\mathrm{Ca}(2)$ was replaced by one $\mathrm{Sr}$ atom in pure $\mathrm{HA}$.

Similarly, $1 \mathrm{Sr}-\mathrm{Ca}(2)-\mathrm{HA} ， 3 \mathrm{Sr}-\mathrm{Ca}(1)-2 \mathrm{Sr}-\mathrm{Ca}(2)-\mathrm{HA}$, 2Sr-Ca(1)-3Sr-Ca(2)-HA, $\quad 1 \mathrm{Sr}-\mathrm{Ca}(1)-4 \mathrm{Sr}-\mathrm{Ca}(2)-\mathrm{HA}$, $5 \mathrm{Sr}-\mathrm{Ca}(2)-\mathrm{HA}$ and $10 \mathrm{Sr}-\mathrm{HA}$ models were built. The stable models after geometric optimization (pure HA, 1Sr-Ca(1)-HA, 2Sr-Ca(1)-3Sr-Ca(2)-HA and 10Sr-HA) are optimized.

All calculations of structure optimization were conducted by the generalized gradient approximation (GGA) of the Perdew-Burke-Ernzerhof (PBE) exchange-correlation which was based on an energy minimization principle. 
The electronic ground state was achieved using a conjugate. The Broyden-Fletcher-Goldfarb-Shanno (BFGS) was utilized to relax the atomic structure. The cutoff energy of the plane waves which was set as $380 \mathrm{eV}$ and the Brillouin zone samplings with a k-point grid of $4 \times 4 \times 4$ samplings were sufficient to guarantee the convergence of total energy. The convergence criteria of geometric optimization and energy were set to (a) a self-consistent field tolerance of $10^{-6} \mathrm{eV} / \mathrm{atom}$, (b) an energy tolerance of $10^{-5} \mathrm{eV} /$ atom, (c) a maximum force tolerance of $0.3 \mathrm{eV} / \mathrm{nm}$, (d) a maximum stress tolerance of $0.05 \mathrm{GPa}$, and (e) a maximum displacement tolerance of $10^{-4} \mathrm{~nm}$. The cell sizes and atomic positions were fully relaxed without any constraints in the process of DFT calculation.

To determine the most stable Sr-doped HA models, the formation energies of different substitution models were calculated by DFT method. The formation energy was evaluated by the following equation ${ }^{[23]}$ :

$$
E_{\text {form }}=E_{\text {doped-HA }}-\left(E_{\mathrm{HA}}-n_{\mathrm{i}} \mu_{\mathrm{Ca}}+n_{\mathrm{i}} \mu_{\mathrm{Sr}}\right)
$$

where $E_{\mathrm{HA}}$ is the energy of perfect HA and $E_{\text {doped-HA }}$ is the energy of doped-HA. $n_{\mathrm{i}}$ denotes the numbers of the corresponding ionic species to be removed from $\left(n_{\mathrm{i}}>0\right)$ or added $\left(n_{\mathrm{i}}<0\right)$ to the HA unit cell. The chemical potentials for $\mathrm{Ca}^{2+}$ and $\mathrm{Sr}^{2+}$ are given by $\mu_{\mathrm{Ca}}$ and $\mu_{\mathrm{Sr}}$, respectively. In this study, the chemical potentials are approximated by their energies at $0 \mathrm{~K}$.

\section{Results and discussion}

\subsection{Chemical composition}

Atomic concentrations of $\mathrm{Ca}, \mathrm{Sr}$, and $\mathrm{P}$ in the nanoparticles were examined by EDS, and the element content was further confirmed by ICP, as listed in Table 1 and Table 2. The results obtained by EDS and ICP were consistent. The ratios of various elements were nearly the same as the raw ratios before the hydrothermal synthesis. The molar ratios of $\mathrm{Ca} / \mathrm{P}$ in $\mathrm{HA}$ and $(\mathrm{Ca}+\mathrm{Sr}) / \mathrm{P}$ in Sr-HA were around 1.67 which was close to the stoichiometric number of pure HA without any significant change after addition of Sr ions, which is similar to previous studies ${ }^{[18-19]}$.

\subsection{Analysis of XRD patterns}

The XRD patterns of particles with different Sr doping concentrations from 0 to $100 \mathrm{at} \%$ are shown in Fig. 1. The diffraction peaks of (002) and (300) shifted to a low $2 \theta$ value with gradual addition of $\mathrm{Sr}$ ions, illustrating an increase of lattice parameters $(a$ and $c$ ) and $d$-spacings. This is because radius of $\mathrm{Sr}$ ion $(0.118 \mathrm{~nm})$ is larger than the radius of $\mathrm{Ca}$ ion $(0.099 \mathrm{~nm})$. These results were in line with those of previous studies ${ }^{[18,24-26]}$. The characteristic diffraction peaks of all XRD patterns were narrow, suggesting good crystallinity of HA and all types of Sr-doped HA nanoparticles. The crystallinity and lattice parameters of all nanoparticles are shown in Table 3. Compared

Table 1 Chemical composition of nanoparticles measured by EDS

\begin{tabular}{cccccccc}
\hline Sample & $\mathrm{Ca} / \mathrm{mol} \%$ & $\mathrm{Sr} / \mathrm{mol} \%$ & $\mathrm{P} / \mathrm{mol} \%$ & $n(\mathrm{Ca}+\mathrm{Sr}) / n(\mathrm{P})$ & $n(\mathrm{Ca}) / n(\mathrm{P})$ & $n(\mathrm{Sr}) / n(\mathrm{P})$ & $n(\mathrm{Sr}) / n(\mathrm{Ca}+\mathrm{Sr})$ \\
\hline HA & 62.02 & 0.03 & 37.95 & - & 1.634 & - & - \\
$10 \% \mathrm{Sr}-\mathrm{HA}$ & 55.98 & 5.64 & 38.38 & 1.605 & 1.459 & 0.147 & 0.092 \\
$50 \% \mathrm{Sr}-\mathrm{HA}$ & 31.85 & 30.59 & 37.56 & 1.662 & 0.847 & 0.814 & 0.490 \\
$100 \% \mathrm{Sr}-\mathrm{HA}$ & 0.05 & 63.85 & 36.10 & - & - & 1.769 & - \\
\hline
\end{tabular}

Table 2 Element content of nanoparticles measured by ICP

\begin{tabular}{cccccccc}
\hline Sample & $\mathrm{Ca} / \mathrm{mol} \%$ & $\mathrm{Sr} / \mathrm{mol} \%$ & $\mathrm{P} / \mathrm{mol} \%$ & $n(\mathrm{Ca}+\mathrm{Sr}) / n(\mathrm{P})$ & $n(\mathrm{Ca}) / n(\mathrm{P})$ & $n(\mathrm{Sr}) / n(\mathrm{P})$ & $n(\mathrm{Sr}) / n(\mathrm{Ca}+\mathrm{Sr})$ \\
\hline HA & 62.19 & 0.06 & 37.75 & - & 1.647 & - & - \\
$10 \% \mathrm{Sr}-\mathrm{HA}$ & 56.49 & 5.77 & 37.74 & 1.649 & 1.497 & 0.153 & 0.093 \\
$50 \% \mathrm{Sr}-\mathrm{HA}$ & 31.85 & 30.57 & 37.58 & 1.660 & 10.848 & 0.813 & 0.490 \\
$100 \%$ Sr-HA & 0.08 & 62.26 & 37.66 & - & - & 1.653 & - \\
\hline
\end{tabular}
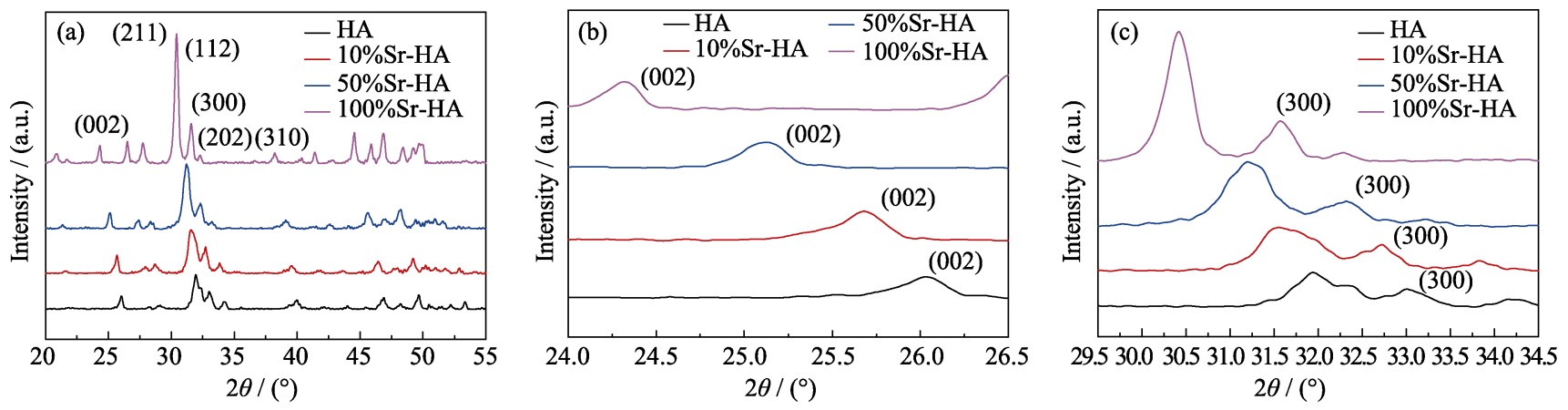

Fig. 1 (a) XRD patterns of HA and Sr-doped HA nanoparticles with (b) magnified (200) peaks, and (c) (300) peaks 
Table 3 Lattice parameters and crystallinity of nanoparticles obtained by XRD

\begin{tabular}{cccccc}
\hline Sample & $\begin{array}{c}\text { Crystallin- } \\
\text { ity }\end{array}$ & $\begin{array}{c}2 \theta_{(002)} / \\
\left({ }^{\circ}\right)\end{array}$ & $\begin{array}{c}2 \theta_{(300)} / \\
\left({ }^{\circ}\right)\end{array}$ & $a / \mathrm{nm}$ & $c / \mathrm{nm}$ \\
\hline HA & $53.3 \%$ & 26.07 & 33.09 & 0.93679 & 0.68286 \\
$10 \% \mathrm{Sr}-\mathrm{HA}$ & $51.1 \%$ & 25.68 & 32.76 & 0.94625 & 0.69326 \\
$50 \% \mathrm{Sr}-\mathrm{HA}$ & $49.4 \%$ & 25.12 & 32.34 & 0.95814 & 0.71056 \\
$100 \% \mathrm{Sr}-\mathrm{HA}$ & $73.7 \%$ & 24.34 & 31.58 & 0.98058 & 0.73071 \\
\hline
\end{tabular}

with pure HA, crystallinites of $10 \% \mathrm{Sr}-\mathrm{HA}$ and $50 \% \mathrm{Sr}-\mathrm{HA}$ were slightly lower while $100 \% \mathrm{Sr}-\mathrm{HA}$ exhibited the highest crystallinity, in that doping of $\mathrm{Sr}$ ions can inhibit the growth of HA nanoparticles. When doping concentration of Sr ions is low, inhibition effect is more obvious, and the irregular grain size leads to crystallinity decrease. When the doping concentration is high up to $100 \%$, it is more likely to form regular and large-size new grains, leading to crystallinity increase. The result was perfectly consistent with the previous report ${ }^{[23]}$. Wang et al. ${ }^{[23]}$ reported that the crystallinities of Sr-doped HA nanoparticles decreased steadily with increasing $\mathrm{Sr}$ content in the range from $10 \mathrm{~mol} \%$ to $50 \mathrm{~mol} \%$. When $\mathrm{Sr}$ reached $100 \mathrm{~mol} \%$, the crystallinity increased suddenly ${ }^{[23]}$.

\subsection{Morphology by SEM observation}

Fig. 2 clearly shows the morphologies of HA and Sr-doped HA nanoparticles. Agglomeration phenomenon occurred in all types of nanoparticles. The pure HA nanoparticles were rod-like. When the doped concentration of $\mathrm{Sr}$ increased from $10 \mathrm{at} \%$ to 50 at $\%$, the morphology of Sr-doped HA did not change significantly compared with the pure HA. With the increase of Sr doping concentration, the crystal length increased, and the $100 \%$ Sr-HA nanoparticles presented rod-like shape and the largest crystal size. Geng et al. ${ }^{[18]}$ also reported similar morphology changes.

\subsection{Morphology and microstructure by TEM observation}

TEM and SAED images of HA and all types of Sr-doped
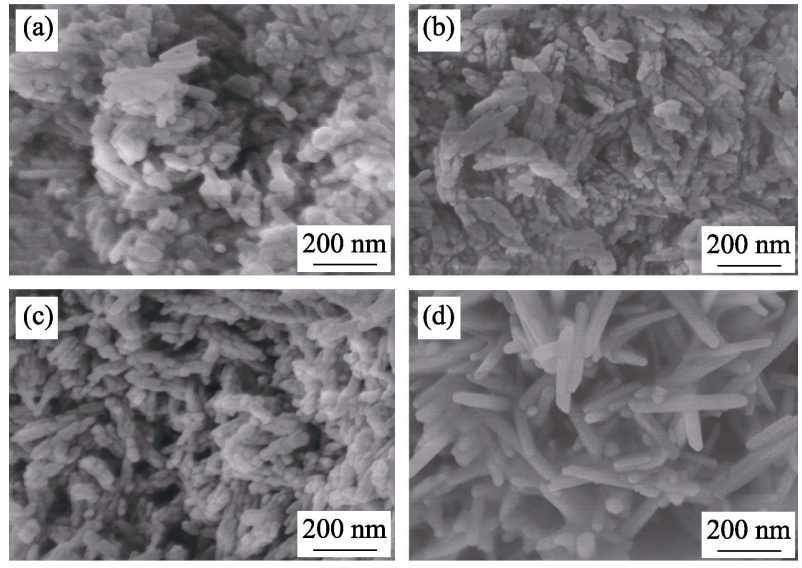

Fig. 2 SEM images of HA and Sr-doped HA nanoparticles (a) $\mathrm{HA}$; (b) $10 \% \mathrm{Sr}-\mathrm{HA}$; (c) $50 \% \mathrm{Sr}-\mathrm{HA}$; (d) $100 \% \mathrm{Sr}-\mathrm{HA}$
HA nanoparticles are displayed in Fig. 3 and Fig. 4. Fig. 3(a, b) show the morphologies of pure HA nanoparticles. Pure HA displays regular shape and the nanoparticles display rod-like shape. Lengths of most nanoparticles vary from 27.5 to $153.2 \mathrm{~nm}$ and the widths of them are between 13 and $27.6 \mathrm{~nm}$. Aspect ratios of crystals are between 2.11 and 7.83. There are no regular morphologies for $10 \%$ Sr-HA nanoparticles (Fig. 3(d, e)), which reveals that the crystal structure of HA was distorted because of the doping of $\mathrm{Sr}$ ions. As the content of doped $\mathrm{Sr}$ increasing to $50 \%$, the irregular crystal size further increased. There was no statistical data about lengths, widths, and aspect ratios of the $10 \% \mathrm{Sr}-\mathrm{HA}$ and $50 \% \mathrm{Sr}-\mathrm{HA}$ nanoparticles due to their irregular shapes. When Sr ions completely replace $\mathrm{Ca}$ ions in $\mathrm{HA}$, most of the nanoparticles regain regular shapes as shown in Fig. 3(j, k). The lengths and aspect ratios of the $100 \% \mathrm{Sr}-\mathrm{HA}$ nanoparticles increased significantly compared to those of other three types of nanoparticles, which are consistent with the results obtained by SEM observation. Most of the 100\% Sr-HA nanoparticles are between 164.7 and $406.2 \mathrm{~nm}$ in length and between 25.5 and $53.9 \mathrm{~nm}$ in width. Their aspect ratios varied from 4.33 to 11.01 . Morphologies of all types of nanoparticles are consistent with the previous studies ${ }^{[19,24]}$.

HRTEM images corresponding to each type of nanoparticle (Fig. 3(c, f, i, l)) were used to analyze the crystal plane $d$-spacing and crystallinity changes of nanoparticles. Pure HA or Sr-doped HA nanoparticles exhibited good crystallinity, as proved by XRD. In pure HA nanoparticles, most of the observed crystal planes were (002) which had a $d$-spacing of $0.34 \mathrm{~nm}$, and was perpendicular to $c$ axis, in consistent with previous study ${ }^{[25]}$. In the nanoparticles doped with $10 \mathrm{at} \%$ and $50 \mathrm{at} \% \mathrm{Sr}$, crystal planes with $d$-spacings of 0.28 and $0.34 \mathrm{~nm}$ can be found. When the doping concentration of $\mathrm{Sr}$ is $100 \%$, only $0.28 \mathrm{~nm}$ crystal plane $\mathrm{d}$-spacing can be observed. SAED patterns (Fig. 4) corresponding to all types of nanoparticles exhibit polycrystalline rings, which is consistent with previous study ${ }^{[18]}$. These results also demonstrated that all types of nanoparticles had good crystallinity, in consistent with XRD and HRTEM results.

\subsection{DFT results}

The unit cells of nine Sr-doped HA models after structure optimization are shown in Fig. 5 and Fig. S1. The calculation results obtained by the DFT method are shown in Table 4. To explore the effect of Sr ions doping into HA crystal structures, the lattice parameters of pure HA unit cell were calculated for comparison. Simulation results well confirmed the accuracy of the experimental ones. 

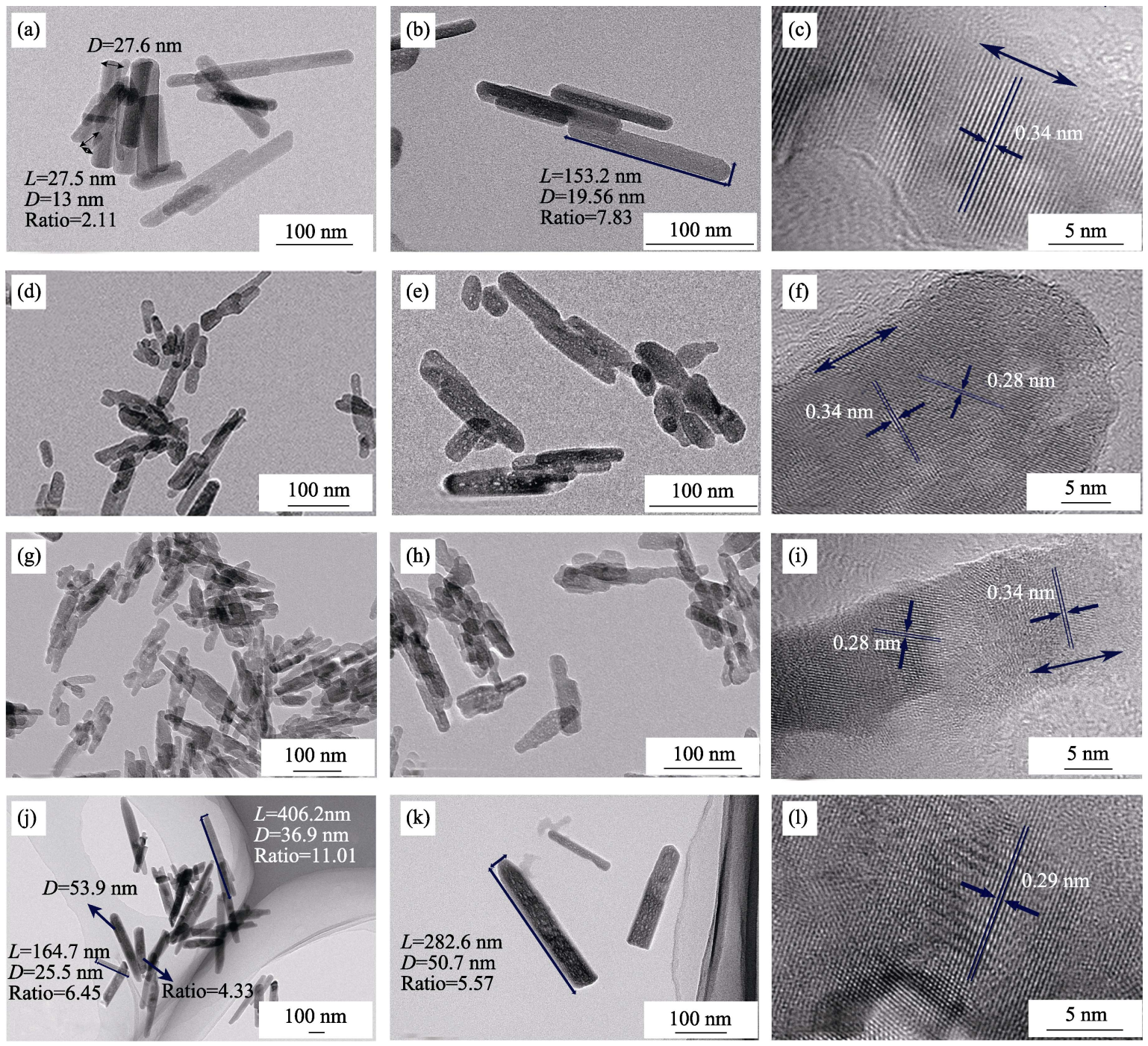

Fig. 3 Morphology of Sr doped HA

(a, b) TEM images of HA; (c) HRTEM image of HA; (d, e) TEM images of 10\%Sr-HA; (f) HRTEM image of 10\%Sr-HA; (g, h) TEM images of $50 \% \mathrm{Sr}-\mathrm{HA}$; (i) HRTEM image of $50 \% \mathrm{Sr}-\mathrm{HA}$; (j, k) TEM images of $100 \% \mathrm{Sr}-\mathrm{HA}$; (1) HRTEM image of $100 \% \mathrm{Sr}-\mathrm{HA}$. Scale bars
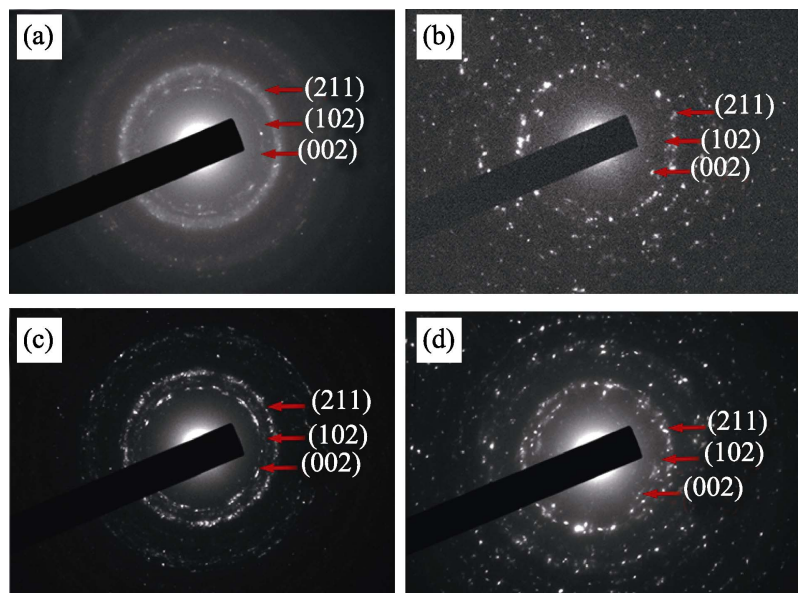

Fig. 4 SAED patterns of samples with different $\mathrm{Sr}$ concentrations (a) $\mathrm{HA}$; (b) $10 \% \mathrm{Sr}-\mathrm{HA}$; (c) $50 \% \mathrm{Sr}-\mathrm{HA}$; (d) $100 \% \mathrm{Sr}-\mathrm{HA}$

The lattice parameters $(a-c)$ obtained by the simulation method were slightly larger than those provided by the experiment method, as shown in Table 4. Lattice (a)

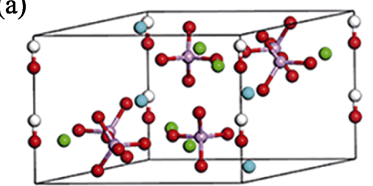

(c)

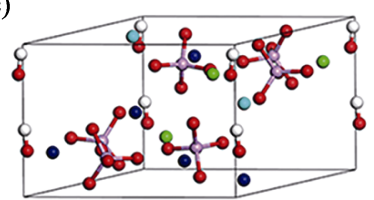

(b)

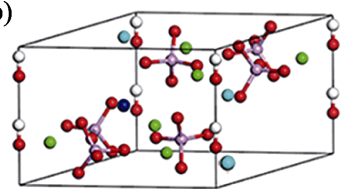

(d)

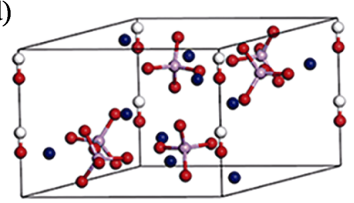

Fig. 5 Unit cell of (a) HA, (b) $1 \mathrm{Sr}-\mathrm{Ca}(1)-\mathrm{HA}$, (c) $2 \mathrm{Sr}-\mathrm{Ca}(1)-$ $3 \mathrm{Sr}-\mathrm{Ca}(2)-\mathrm{HA}$, (d) 10Sr-HA after structural optimization Calcium (1): light blue; Calcium (2): green; Strontium: dark blue; Phosphorus: pink; Oxygen: red; Hydrogen: white

parameters (both $a$ and $c$ ) of all types of Sr-doped HA unit cells distinctly increased with increasing $\mathrm{Sr}$ concentrations, no matter which sites $[\mathrm{Ca}(1)$ or $\mathrm{Ca}(2)]$ were substituted by $\mathrm{Sr}$ ions. For $10 \% \mathrm{Sr}-\mathrm{HA}$ models, the lattice 
Table 4 Lattice parameters and formation energy calculated by DFT method and lattice parameters $(a \& c)$ obtained from experiments

\begin{tabular}{|c|c|c|c|c|c|c|}
\hline Method & Model & $a / \mathrm{nm}$ & $b / \mathrm{nm}$ & $c / \mathrm{nm}$ & $V / \mathrm{nm}^{3}$ & Formation energy/eV \\
\hline \multirow{9}{*}{ DFT } & HA & 0.9642 & 0.9642 & 0.6853 & 5517 & \\
\hline & $1 \mathrm{Sr}-1 \mathrm{Ca}(1)-\mathrm{HA}$ & 0.9695 & 0.9695 & 0.6910 & 5595 & -0.307 \\
\hline & $1 \mathrm{Sr}-1 \mathrm{Ca}(2)-\mathrm{HA}$ & 0.9717 & 0.9727 & 0.6897 & 5603 & -0.250 \\
\hline & $4 \mathrm{Sr}-4 \mathrm{Ca}(1)-1 \mathrm{Sr}-1 \mathrm{Ca}(2)-\mathrm{HA}$ & 0.9724 & 0.9744 & 0.7219 & 5879 & -0.404 \\
\hline & $3 \mathrm{Sr}-3 \mathrm{Ca}(1)-2 \mathrm{Sr}-2 \mathrm{Ca}(2)-\mathrm{HA}$ & 0.9765 & 0.9799 & 0.7159 & 5897 & -0.346 \\
\hline & $2 \mathrm{Sr}-2 \mathrm{Ca}(1)-3 \mathrm{Sr}-3 \mathrm{Ca}(2)-\mathrm{HA}$ & 0.9778 & 0.9841 & 0.7117 & 5891 & -0.557 \\
\hline & $1 \mathrm{Sr}-1 \mathrm{Ca}(1)-4 \mathrm{Sr}-4 \mathrm{Ca}(2)-\mathrm{HA}$ & 0.9788 & 0.9869 & 0.7108 & 5894 & -0.369 \\
\hline & $5 \mathrm{Sr}-5 \mathrm{Ca}(2)-\mathrm{HA}$ & 0.9809 & 0.9861 & 0.7113 & 5906 & -0.259 \\
\hline & 10Sr-HA & 0.9922 & 0.9922 & 0.7361 & 6274 & -0.321 \\
\hline \multirow{4}{*}{ Experiment } & HA & 0.9368 & - & 0.6829 & - & - \\
\hline & $10 \% \mathrm{Sr}-\mathrm{HA}$ & 0.9463 & - & 0.6933 & - & - \\
\hline & $50 \% \mathrm{Sr}-\mathrm{HA}$ & 0.9581 & - & 0.7106 & - & - \\
\hline & $100 \% \mathrm{Sr}-\mathrm{HA}$ & 0.9806 & - & 0.7307 & - & - \\
\hline
\end{tabular}

parameters $a, b$, and $c$ of $1 \mathrm{Sr}-\mathrm{Ca}(2)-\mathrm{HA}$ and $1 \mathrm{Sr}-\mathrm{Ca}(1)-\mathrm{HA}$ models were larger than those of pure HA model. For $50 \% \mathrm{Sr}-\mathrm{HA}$ and $100 \% \mathrm{Sr}-\mathrm{HA}$ models, the results were roughly the same as that of the $10 \% \mathrm{Sr}-\mathrm{HA}$ model and in line with the previous studies ${ }^{[19,23]}$.

Negative formation energy of all types of Sr-doped HA models suggested that Sr doping enhanced the stability of the apatite crystal structure. For 10at $\%$ Sr-HA models, results of formation energy showed that $1 \mathrm{Sr}-\mathrm{Ca}(1)-\mathrm{HA}$ model was more stable than $1 \mathrm{Sr}-\mathrm{Ca}(2)-\mathrm{HA}$ model. At $10 \mathrm{at} \%$ doping concentration, $\mathrm{Sr}^{2+}$ was more likely to replace $\mathrm{Ca}^{2+}$ ion at $\mathrm{Ca}(1)$ position. Therefore, $\mathrm{Ca}(1)$ site was the preferential site for $\mathrm{Sr}$ doping at $10 \% \mathrm{Sr}$ concentration, which was in line with the previous report $^{[27]}$. For $50 \% \mathrm{Sr}-\mathrm{HA}$ models, $2 \mathrm{Sr}-\mathrm{Ca}(1)-3 \mathrm{Sr}-\mathrm{Ca}(2)-\mathrm{HA}$ model was the most stable model owing to its lowest negative formation energy, which was consistent with the previous study ${ }^{[23]}$.

\section{Conclusions}

In this work, HA, $10 \% \mathrm{Sr}-\mathrm{HA}, 50 \% \mathrm{Sr}-\mathrm{HA}$, and $100 \% \mathrm{Sr}-\mathrm{HA}$ were prepared by a hydrothermal synthesis method. The conclusions can be drawn as follows:

1) All HA and Sr-doped HA nanoparticles have good crystallinity and show polycrystalline properties. Crystallinity of $10 \% \mathrm{Sr}-\mathrm{HA}$ and $50 \% \mathrm{Sr}-\mathrm{HA}$ are lower than that of pure HA. When Sr concentration reaches $100 \mathrm{at} \%$, the crystallinity becomes the highest.

2) Lattice parameters $a$ and $c$ of HA unit cell increases with increasing concentration of $\mathrm{Sr}$ ions. Stabilities of the $\mathrm{Sr}-\mathrm{HA}$ nanoparticles enhance with the doping of $\mathrm{Sr}$ ions due to their negative formation energy. The $2 \mathrm{Sr}-2 \mathrm{Ca}(1)-$ $3 \mathrm{Sr}-3 \mathrm{Ca}(2)-\mathrm{HA}$ model is more stable than the others because of its minimum formation energy.

\section{Supporting materlals:}

Supporting materlals related to this article can be found at https://doi.org/10.15541/jin20180439.

\section{References:}

[1] SADAT-SHOJAI M, KHORASANI M T, DINPANAH-KHOSHDARGI E, et al. Synthesis methods for nanosized hydroxyapatite with diverse structure. Acta Biomaterialia, 2013, 9(8): 7591-7621.

[2] LANDI E, TAMPIERI A, MATTIOLI-BELMONTE M, et al. Biomimetic $\mathrm{Mg}$-and $\mathrm{Mg}, \mathrm{CO}_{3}$-substituted hydroxyapatites: synthesis characterization and in vitro behaviour. Journal of the European Ceramic Society, 2006, 26(13): 2593-2601.

[3] WANG H, LEE J K, MOURSI A, et al. Ca/P ratio effects on the degradation of hydroxyapatite in vitro. Journal of Biomedical Materials Research Part A, 2003, 67(2): 599-608.

[4] SHI Z, HUANG X, CAI Y, et al. Size effect of hydroxyapatite nanoparticles on proliferation and apoptosis of osteoblast-like cells. Acta Biomaterialia, 2009, 5(1): 338-345.

[5] THIAN E, KONISHI T, KAWANOBE Y, et al. Zinc-substituted hydroxyapatite: a biomaterial with enhanced bioactivity and antibacterial properties. Journal of Materials Science: Materials in Medicine, 2013, 24(2): 437-445.

[6] XIU Z, LÜ M, LIU S, et al. Barium hydroxyapatite nanoparticles synthesized by citric acid Sol-Gel combustion method. Materials Research Bulletin, 2005, 40(9): 1617-1622.

[7] GE X, LENG Y, BAO C, et al. Antibacterial coatings of fluoridated hydroxyapatite for percutaneous implants. Journal of Biomedical Materials Research - Part A, 2010, 95(2): 588-599.

[8] GE X, LENG Y, REN F, et al. Integrity and zeta potential of fluoridated hydroxyapatite nanothick coatings for biomedical applications. Journal of the Mechanical Behavior of Biomedical Materials, 2011, 4(7): 1046-1056.

[9] GE X, REN C, LU X, et al. Surfactant-free electrochemical synthesis of fluoridated hydroxyapatite nanorods for biomedical applications. Ceramics International, 2019, 45(14): 17336-17343.

[10] YOUNESS R A, TAHA M A, IBRAHIM M. In vitro bioactivity, physical and mechanical properties of carbonated-fluoroapatite during mechanochemical synthesis. Ceramics International, 2018, 
44(17): 21323-21329.

[11] SEDELNIKOVA M B, KOMAROVA E G, SHARKEEV Y P, et al. Modification of titanium surface via Ag-, Sr-and Si-containing micro-arc calcium phosphate coating. Bioactive Materials, 2019, 4: 224-235.

[12] BOANINI E, TORRICELLI P, GAZZANO M, et al. Combined effect of strontium and zoledronate on hydroxyapatite structure and bone cell response. Biomaterials, 2014, 35(21): 5619-5626.

[13] PENG S, ZHOU G, LUK K D, et al. Strontium promotes osteogenic differentiation of mesenchymal stem cells through the Ras/MAPK signaling pathway. Cellular Physiology and Biochemistry, 2009, 23(1/2/3): 165-174.

[14] ZHOU J, LI B, LU S, et al. Regulation of osteoblast proliferation and differentiation by interrod spacing of Sr-HA nanorods on microporous titania coatings. ACS Applied Materials \& Interfaces, 2013, 5(11): 5358-5365.

[15] LAURENCIN D, WONG A, HANNA J V, et al. A high-resolution 43Ca solid-state NMR study of the calcium sites of hydroxyapatite. Journal of the American Chemical Society, 2008, 130(8): 2412-2413.

[16] LI P, JIA Z, WANG Q, et al. A resilient and flexible chitosan/silk cryogel incorporated $\mathrm{Ag} / \mathrm{Sr}$ co-doped nanoscale hydroxyapatite for osteoinductivity and antibacterial properties. Journal of Materials Chemistry B, 2018, 6(45): 7427-7438.

[17] ZEGLINSKI J, NOLAN M, BREDOL M, et al. Unravelling the specific site preference in doping of calcium hydroxyapatite with strontium from $a b$ initio investigations and Rietveld analyses. Physical Chemistry Chemical Physics, 2012, 14(10): 3435-3443.

[18] GENG Z, CUI Z, LI Z, et al. Synthesis, characterization and the formation mechanism of magnesium-and strontium-substituted hydroxyapatite. Journal of Materials Chemistry B, 2015, 3(18):
3738-3746.

[19] BIGI A, BOANINI E, CAPUCCINI C, et al. Strontium-substituted hydroxyapatite nanocrystals. Inorganica Chimica Acta, 2007, 360(3): 1009-1016.

[20] TERRA J, DOURADO E R, EON J G, et al. The structure of strontium-doped hydroxyapatite: an experimental and theoretical study. Physical Chemistry Chemical Physics, 2009, 11(3): 568-577.

[21] WEBSTER T J, MASSA-SCHLUETER E A, SMITH J L, et al. Osteoblast response to hydroxyapatite doped with divalent and trivalent cations. Biomaterials, 2004, 25(11): 2111-2121.

[22] LANDI E, TAMPIERI A, CELOTTI G, et al. Densification behaviour and mechanisms of synthetic hydroxyapatites. Journal of the European Ceramic Society, 2000, 20(14/15): 2377-2387.

[23] WANG Q, LI P, TANG P, et al. Experimental and simulation studies of strontium/fluoride-codoped hydroxyapatite nanoparticles with osteogenic and antibacterial activities. Colloids and Surfaces B: Biointerfaces, 2019, 182: 110359.

[24] LI Z H, WU J M, HOAN S J, et al. Preparation and property of strontium-substituted hydroxyapatite. Journal of Inorganic Materials, 2011, 26(1): 49-54.

[25] LI Z Y, LAM W M, YANG C, et al. Chemical composition, crystal size and lattice structural changes after incorporation of strontium into biomimetic apatite. Biomaterials, 2007, 28(7): 1452-1460.

[26] WANG Q, TANG P, GE X, et al. Experimental and simulation studies of strontium/zinc-codoped hydroxyapatite porous scaffolds with excellent osteoinductivity and antibacterial activity. Applied Surface Science, 2018, 462: 118-126.

[27] MATSUNAGA K, MURATA H. Strontium substitution in bioactive calcium phosphates: a first-principles study. The Journal of Physical Chemistry B, 2009, 113(11): 3584-3589.

\title{
掺锶羟基磷灰石纳米颗粒的合成、表征及模拟研究
}

\author{
周子航 ${ }^{1}$, 王 群 ${ }^{2}$, 葛 翔 $^{3}$, 李朝阳 ${ }^{1}$
}

(1. 天津大学 材料科学与工程学院, 天津 $300350 ; 2$. 绵阳师范学院 生命科学与技术学院, 绵阳 621000 ; 3. 天津 大学 机械工程学院, 机构理论与装备设计教育部重点实验室, 天津 300354)

摘 要: 锶 $(\mathrm{Sr})$ 掺杂羟基磷灰石(HA)在生物材料中得到广泛应用。在此研究中, 使用水热合成的方法制备 $\mathrm{HA}$ 和 $\mathrm{Sr}$ 掺杂 HA 的纳米颗粒。通过实验和计算机模拟的方法研究 $\mathrm{Sr}$ 掺杂对 HA 化学成分、结晶度、晶格参数、形貌和形 成能的影响。实验结果表明, $\mathrm{Sr}$ 掺杂后的 $\mathrm{HA}$ 纳米颗粒晶格参数和晶体尺寸增大。随着 $\mathrm{Sr}$ 离子浓度的增加, $\mathrm{Sr}$ 掺杂 $\mathrm{HA}$ 的纳米颗粒的结晶度没有显著变化。模拟结果验证了实验得到的 $\mathrm{Sr}$ 掺杂 $\mathrm{HA}$ 纳米颗粒晶格参数的准确性, 且进 一步表明 $\mathrm{Sr}$ 离子掺杂后纳米颗粒的形成能较低, 结构更稳定。当 $\mathrm{Sr}$ 掺杂浓度为 $10 \%$ 时, $\mathrm{Sr}$ 掺杂的优先位点是 $\mathrm{Ca}(1)$; $\mathrm{Sr}$ 掺杂浓度为 $50 \%$ 时, $\mathrm{Sr}$ 混合掺杂到 $\mathrm{Ca}(1)$ 和 $\mathrm{Ca}(2)$ 位点为更优先的掺杂模式。

关 键 词: 羟基磷灰石; 锶掺杂; 晶格参数; 密度泛函理论; 形成能

中图分类号: TQ174 文献标识码: A 
Supporting Materlals:

\title{
Strontium Doped Hydroxyapatite Nanoparticles: Synthesis, Characterization and Simulation
}

\author{
ZHOU Zihang ${ }^{1}$, WANG Qun ${ }^{2}$, GE Xiang ${ }^{3}$, LI Zhaoyang ${ }^{1}$
}

(1. School of Materials Science and Engineering, Tianjin University, Tianjin 300350, China; 2. College of Life Science and Biotechnology, MianYang Teachers' College, Mianyang 621006, China; 3. Key Laboratory of Mechanism Theory and Equipment Design of Ministry of Education, School of Mechanical Engineering, Tianjin University, Tianjin 300354, China)

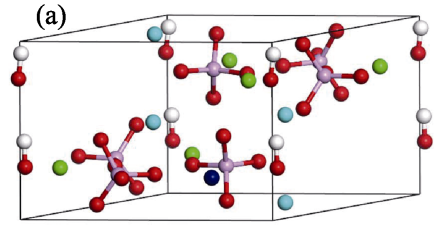

(d)

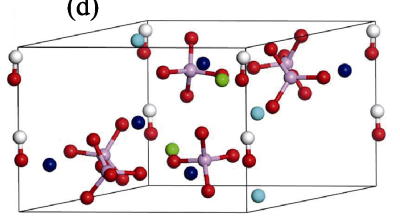

(b)

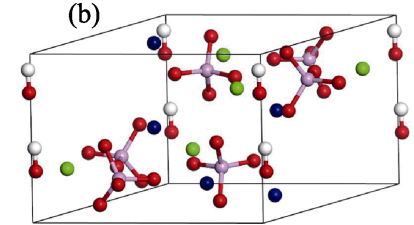

(c)

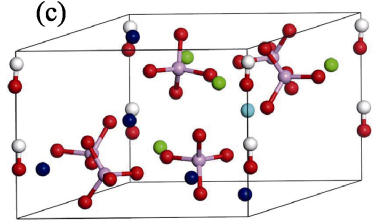

(e)

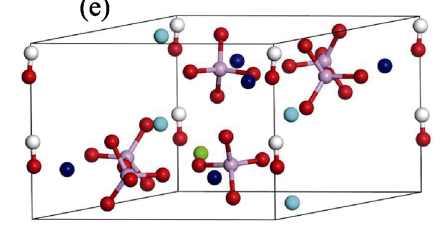

Fig. S1 The unit cell of (a) $1 \mathrm{Sr}-\mathrm{Ca}(2)-\mathrm{HA}$, (b) 4Sr-Ca(1)-1 Sr-Ca(2)-HA, (c) 3Sr-Ca(1)-2Sr-Ca(2)-HA,

(d) $1 \mathrm{Sr}-\mathrm{Ca}(1)-4 \mathrm{Sr}-\mathrm{Ca}(2)-\mathrm{HA}$, (e) $5 \mathrm{Sr}-\mathrm{Ca}(2)-\mathrm{HA}$ after structural optimization. Color codes: Calcium (1): light blue,

Calcium (2): green, Strontium: dark blue, Phosphorus: pink, Oxygen: red, Hydrogen: white 